\title{
SELECTION FOR IMMUNE RESPONSE IN JAPANESE QUAILS
}

\author{
M.A. Mandour * M.M. Sharaf* and M.A. Helal ${ }^{* *}$ \\ *Animal Husbandry Department, Faculty of Veterinary Medicine, Alexandria University \\ ${ }^{* *}$ Faculty of Veterinary Medicine, Minoufyia University
}

\section{ABSTRACT}

Japanese quails were divergently selected for antibody titer to inactivated Newcastle disease virus vaccine. Correlated responses of body weight at different ages, egg weight and egg number (first 45 days), fertility and hatchability percentages, some serum parameters and phagocytic activity were also estimated.

Actual selection differential values from the base to the first, from the first to the second, from the second to third and from the base to the third generations were $2.54,1.96,1.4$ and 5.9, respectively, in the high line and-2.4, - 2.47, -1.35 and-6.22, respectively in the low line. The average response per generation was 0.88 and - 0.93 in the high and low lines, respectively. Cumulative correlated response was 0.21 and-0.09 $\mathrm{g}$ in both high and low lines. The correlated response of egg number and egg weight during the first 45 days of egg production and hatchability percentage was small and insignificant in both selected lines. Differences in phagocytic activity or phagocytic index among lines were insignificant. Serum from quails of the high line was significantly $(P<0.01)$ higher in total serum protein $(4.61 \pm 0.47 \mathrm{~g} / 100 \mathrm{ml})$, globulin $(2.80 \pm 0.47$ $\mathrm{g} / 100 \mathrm{ml})$ and gamma globulin $(0.51 \pm 0.02 \mathrm{~g} / 100 \mathrm{ml})$ than the low line (total protein, 3.05 $\pm 0.38 ;$ globulin, 1.52 $\pm 0.38 ;$ gamma globulin, 0.44 \pm 0.02 ).

(Key words: divergent, selection, immune response, quails)

\section{INTRODUCTION}

Infectious diseases are responsible for major economic losses in noultry inductry Ffficient noultry nroduction is dependent upon a fend against disease.

vithout actually challenging animals 
with disease agent is desirable. Indirect selection based on suitable genetic markers represented an ideal approach to the improvement of disease resistance, since it did not require exposure to pathogens. In some experiments, selection was based on immune response to a single antigen, such as sheep red blood cells, a complex non pathogenic T-cell dependent antigen (Siegel and Gross, 1980; Van der Zijpp, 1983; Martin et. al., 1990, Pinard et. al., 1992) or to inactivated virus such as Newcastle disease virus (Takahashi et. al., 1984, Pitcovski et. al., 1987) and also for E.coli vaccine (Leitner et al., 1992).

Japanese quail was selected for high and low antibody response (Takahashi et. al.; 1984). After seven generations, the serum antibody level in the high line was $24 \%$ higher than the level in unselected control, whereas the low line antibody level was approximately $37 \%$ less than that in the control line.

Dunnington et al. (1996) reported that long term selection for divergent antibody titers was accompanied by a difference in body weight with low line Leghorn chickens heavier than the high line ones. Also sexual maturity was delayed in the line of chickens selected for high antibody response. Parmentier et al. (1996) reported that body weights of ISA Warren cross chickens at five and 17 weeks of age in the low line were significantly heavier than those of the high line. Hens of the control line had an intermediate body weight. Also cocks of the low line were significantly heavier than those of the high line at 17 weeks of age. The aim of the present work was to investigate the effect of divergent selection for immune response to inactivated Newcastle disease virus vaccine and to study the correlated responses of body weight at different ages, egg production, egg weight, fertility and hatchability, egg qualtiy traits, some serum parameters and phagocytic activity.

\section{MATERIALS \& METHODS}

This work was carried out on Japanese quail (Coturnix coturnix japonica) belonging to the Animal Husbandry Department, Faculty of Veterinary Medicine, Alexandria University during 1997-1998. 


\section{Flock Management:-}

Sire families (single pair matings) were housed in wire cages $(25 \times$ $25 \times 25 \mathrm{~cm}$ ). Eggs were collected every morning, numbered according to their families and weighted to the nearest 0.1 gram. Eggs were stored at room temperature and set weekly in forced air incubator.

\section{Feeding:-}

Quails were fed ad-libitum and the chemical analysis of the ration used is presented in Table 1.

Table 1: Chemical analysis of the ration used.

\begin{tabular}{|l||c||c|}
\hline & Starting and growing diet \% & Laying diet $\%$ \\
\hline \hline Proximate chemical analysis:- & & \\
Moisture & 10.6 & 9.9 \\
Crude protein & 23.99 & 20.1 \\
Ether extract & 5.10 & 6.70 \\
Crude fiber & 3.60 & 3.30 \\
Metabolizable energy Kcal/Kg & 2998.80 & 2966.90 \\
Calcium & 0.89 & 2.97 \\
\hline
\end{tabular}

\section{The vaccine and immunization:-}

Emulsified inactivated vaccine against Newcastle Disease (IZO S.P.A). Each dose of $0.5 \mathrm{ml}$ of vaccine contains inactivated Newcastle Disease Virus $>50$ PD50. Birds at 4 weeks of age were immunized by intramuscular injection with $0.5 \mathrm{ml}$ of the vaccine. Two weeks later they were re-immunized with a $0.5 \mathrm{ml}$ via intramuscular injection (Takahashi et al., 1984).

\section{Blood samples collection and Separation of the serum:-}

Blood samples were collected from wing vein. Clotted blood samples were centrifuged at 3000 r.p.m. For 15 minutes to obtain clear serum. The serum samples were kept in small labeled sterile tubes and stored at $-20{ }^{\circ} \mathrm{C}$ till used (Stoot and Fellah, 1983). 


\section{Hemagglutination Inhibition test (HI):-}

Was done According to Graham et al., (1989). The titers were expressed as $\log _{2}$ of the reciprocal of the last dilution showing HI.

\section{Selection Procedures:-}

Approximately 655 progenies from 85 paired matings were wing banded at hatching according to their families. Selection procedures based on the individual antibody titer ( $\log 2$ transformed value) one week after the second immunization (at seven weeks of age). Two groups were selected from the original population. One group consisted of all individual birds which had antibody titer greater than one half standard deviation $(\mu+0.5$ SD) above the population mean titer. This group was designated as the high line. All individual birds which had antibody titer less than one half standard deviation below the population mean titer $(\mu$ $0.5 \mathrm{SD}$ ) were designated as the low line. Selection was not changed at any time during the experiment in the two selected lines. Selected females (one female) were mated to a single male, and matings between half sibs or more closely related individuals were avoided.

Within each generation data were corrected for hatch before selection. Numbers and proportions selected within each line within each generation are shown in Table 2. A non selected random mating control population was also maintained by the same management procedures.

Table2: Number of tested quails, number of selected quails, proportion selected and selection intensity within each generation:

\begin{tabular}{|c||c||c||c||c||c|}
\hline Generation & Line & Total number & Number selected & Proportion selected & Selection intensity \\
\hline \hline \multirow{2}{*}{ Base } & High & 655 & 128 & 19.54 & 1.43 \\
& Low & & 125 & 19.08 & 1.35 \\
\hline \multirow{2}{*}{ First } & High & 186 & 50 & 26.80 & 1.69 \\
& Low & 188 & 52 & 27.65 & 1.68 \\
\hline \multirow{2}{*}{ Second } & High & 128 & 51 & 39.80 & 1.31 \\
& Low & 146 & 35 & 32.97 & 1.20 \\
\hline \multirow{2}{*}{ Third } & High & 90 & & & \\
& Low & 92 & & & \\
\hline
\end{tabular}

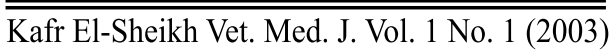




\section{Studied traits:-}

1. Antibody titer to inactivated Newcastle disease virus vaccine at 7 weeks of age expressed as $\log 2$ of the reciprocal of the last dilution showing HI.

2. Body weight at Hatch, two weeks, four weeks and six weeks of age in grams in all birds in the selected and control lines.

3. Egg number and egg weight in grams during the first 45day of production (Bahie El-Dean, 1990).

4. Fertility percentage: measured by dividing the number of fertile eggs by total number of eggs set multiplied by one hundred for each line.

5. Hatchability percentage measured as the percentage of hatched chicks to the number of fertile eggs for each line.

\section{Estimation of phagocytosis:-}

Phagocytic activity was determined according to Kawahara et al. (1991).

\section{Estimation of total serum protein:-}

The total serum protein was determined using Buiret reagent (using method of Weichselbaum, 1946).

10.Estimation of serum albumin:- (Bartholomew and Delancy, 1966).

\section{Estimation of serum globulins:-}

Serum globulins were calculated by substrating the serum albumen value from total serum protein of the same sample (Coles, 1974).

12.Estimation of serum gamma globulins:- (Walfson et al., 1948).

\section{Statistical Analysis:-}

Data were analyzed using the General Linear Model procedures of Statistical Analysis System (1987). Data were adjusted for hatch effect. 
Arc Sine transformation was done to fertility and hatchability percentages (Gomez and Gomez, 1984).

\section{Statistical Model:-}

$$
\begin{aligned}
& Y_{i j k}=\mu+G_{i}+L_{j}+e_{i j k} \\
& Y_{i j k}=\text { Is the } k^{\text {th }} \text { observation in the } i^{\text {th }} \text { generation in the } j^{\text {th }} \text { line } \\
& \mu \quad=\text { Is the general mean } \\
& \mathrm{G}_{\mathrm{i}}=\text { Effect of generation } \\
& \mathrm{L}_{\mathrm{j}}=\text { Effect of line } \\
& \mathrm{e}_{\mathrm{ijk}}=\text { Random error }
\end{aligned}
$$

\section{RESULTS \& DISCUSSION}

\section{I.Selection for high or low antibody titer:-}

Least squares means and their standard errors for serum antibody levels ( $\log _{2}$ transformed values to inactivated Newcastle disease virus (NDV) vaccine with the numbers of progeny tested across three generations of divergent selection for high and low antibody titer are listed in Table (3). The response to selection for high and low antibody titer to inactivated NDV vaccine was immediate as evidenced by the highly significant difference $(\mathrm{P}<0.01)$ between the high and low lines (1.64), control and low lines (1.14) and high and control lines (0.5) in the first generation. These differences became progressively larger in successive generations (In the same order, 4.1, 2.13 and 1.97; in the second generation and 5.34, 2.81 and 2.62 in the third generation of selection).

Comparing the actual and expected selection differentials revealed non significant difference. Therefore, natural selection exerted a little influence on the response to artificial selection for antibody titer to inactivated NDV vaccine Table (4).

Intensity of selection was slightly larger in the high line than in the low line this difference was not statistically significant (Table 4). 
The difference between means of the succeeding generations in the selected lines was utilized to measure the response to selection. Differences between the base and first, first and second and second and third generations were highly significant $(\mathrm{P}<0.01)$ (Table 3$)$. The average response per generation was 0.88 and-0.93 in the high and low lines, respectively. The difference in average response between the high and low lines was 0.06 and was judged as being statistically non significant $(\mathrm{P}>0.05)$.

Sex differences, within line, in immune response to inactivated NDV vaccine were not significant. Least square means and their standard errors and number of male and female progeny tested within each line in each generation are listed in Table (5).

The response to selection for high and low antibody titers to inactivated NDV vaccine was consistent with that noted for quails by Takahashi et al. (1984). High line was $24.4 \%$ greater than the unselected control line, whereas the low line antibody level was $11.3 \%$ less than control one. Siegel and Gross (1980) reported a highly significant difference (3.07 for males and 2.84 for females, $\log _{2}$ transformed values) between the high and low lines after three generations of selection. Sex differences were not significant. Martin et al. (1990), after fourteen generations of selection, reported a highly significant difference $\left(5.9, \log _{2}\right.$ transformed value) between the high and low lines. Pinard et al. (1992), after three generations, found a highly significant difference between the selected and control lines (reached 4.3 in the ninth generation). Pitcovski et al., 1987 reported a combined response for high lines as 68\% higher than lines selected for low response to the NDV vaccine. It could be concluded that, there was additive and non-additive genetic variation for immune response to inactivated NDV vaccine. Selection for antibody titer to inactivated NDV vaccine resulted in a cumulative genetic improvement equal to 2.63 ( $\log _{2}$ transformed value) in immune response to NDV vaccine (Table 4 


\section{Observed Correlated response to selection:-}

\section{a. Body weight at different ages:-}

Least squares means for body weight at day of hatch, 2, 4 and 6 weeks of age within each line within each generation are presented in Table 6. The actual correlated response in these traits to selection for high antibody titer are presented in Table 7.

Results indicated that divergent selection for high antibody titer to inactivated NDV vaccine did not adversely affect body weight in Japanese quail. Moreover, selection for high antibody titer had a positive effect on body weight at four and six weeks of age. Similar results were obtained in quail by Takahashi et al. (1984). They reported that after nine generations of divergent selection for antibody response against inactivated NDV vaccine, no significant differences in body weight were obtained among lines of selected quail. In chickens, Pitcovski et al. (1987) selected broilers for antibody response against E. coli and NDV vaccines and they found that the high line chickens were significantly heavier than the low line ones. Leitner et al. (1992) reported no correlated responses in body weight at marketing in broilers divergently selected for antibody response against E. coli vaccine at 10 days of age.

On the other hand, these results are not in agreement with those reported by Siegel and Gross (1980) who selected chickens divergently for immune response against sheep red blood cells for three generations. They concluded that the low line chickens were significantly heavier in 4-week body weight than their high or control counterparts which did not differ from each other. Martin et al. (1990) reported that body weights in the low line were greater in the low line than those in the high line at 4 and 24 weeks of age in chickens selected for antibody response against sheep red blood cells.

Dunnington et al. (1996) after five generations of selection for antibody response against sheep red blood cells, their results indicated that chickens of the low lines were significantly heavier than those of the high and control lines. Parmentier et al. (1996) reported that chickens selected for low antibody response against sheep red blood cells were significantly heavier at 5 and 17 weeks of age than those selected for high titer.

Kafr El-Sheikh Vet. Med. J. Vol. 1 No. 1 (2003) 


\section{b.Fertility and hatchability:}

Least squares means and their standard errors for fertility and hatchability percentages within lines of quail selected for high or low antibody titer to inactivated NDV vaccine across three generations are presented in Table (8).

Results (cumulative correlated response from base to the third generation, Table 9) suggested that fertility and hatchability of quail eggs were not significantly affected by divergent selection for antibody titer to inactivated NDV vaccine. Similar results were obtained by Takahashi et al. (1984) who concluded that after nine generations of selection for antibody titer to inactivated NDV vaccine, no differences were detected in fertility or hatchability among lines of quail. However, these results are not consistent with the findings of Pitcovski et al. (1987) who selected broilers divergently for early responsiveness to E. coli and NDV vaccines for four generations. They found that the fertility percentage in the high line was significantly higher $(\mathrm{P}<0.01)$ than the low line while no differences were obtained in hatchability among lines.

\section{c. Egg production:-}

Least squares means of egg number and egg weight during the first 45 days of production are listed in Table (10). There was non significant differences in egg number among lines within the same generation. Correlated response to selection in egg number (differences among means of the same line in successive generations) from base to the first, the first to the second, from the second to the third and from base to the third generation was positive but insignificant $(\mathrm{P}>0.05)$ (Table 11).

It could be concluded that selection for immune response to inactivated NDV vaccine does not affect significantly egg production in Japanese quail. These results are in agreement with those found by Takahashi et al. (1984) who detected no differences in egg production in quail divergently selected for immune response to NDV vaccine. On the other hand, these results are not in agreement with the findings of Pitcovski et al. (1987) who observed greater egg number in the high line of broilers selected for early responsiveness to E.coli and NDV vaccine. 
M. A. Mandour, et al.

Martin et al. (1990) observed greater egg production in low line of chickens selected for immune response to sheep red blood cells.

\section{d. Phagocytosis:-}

Differences in phagocytic activity of the high, low and control lines during selection against inactivated NDV vaccine were investigated in the third generation of selection. Least squares means and their standard errors for phagocytic activity (\% of phagocytic cells) and phagocytic index (number of yeast cells phagocytized) in the three lines are presented in Table (12).

The results showed that among lines differences in phagocytic activity or phagocytic index were statistically non significant. However, both low and control lines were numerically $(30.00 \pm 2.00 \%)$ higher than the high line $(26.00 \pm 1.00 \%)$ in phagocytic activity but the phagocytic cells in the high line phogocytized more yeast cells $(8.51 \pm 0.47)$ than both control $(8.04 \pm 0.75)$ or low $(7.98 \pm 0.39)$ lines.

These results are in agreement with the findings of Cheng and Lamont (1988) who found non significant correlation between antibody response against Pasteurella multocida and Mycoplasma gallisepticum and phagocytosis. They suggested that these results indicating relative independence of these components of the immune system. Also Kreukniet et al. (1995) observed no differences in the total clearance capacity of the phagocytes, measured by clearance of carbon particles from blood, between high and low lines of chickens selected for antibody response against sheep red blood cells. They added that granulocytes of the high line phagocytized more yeast cells than those of the low line. They concluded that the difference in antibody response was not due to measurable differences in phagocytic activity.

On the other hand, these results are not consistent with those obtained in mouse by Biozzi et al. (1979) who reported a negative correlation between antibody production and phagocytic activity in lines of mice divergently selected for immune response against sheep red blood cells. 


\section{e.Serum parameters:-}

Total serum protein, serum albumen, globulin and gamma globulin were investigated in quails of the high, low and control lines in the third generation of selection. Least squares means and their standard errors for these parameters have been listed in Table (13). Serum from quails of the high line was significantly $(\mathrm{P}<0.01)$ higher in total serum protein $(4.61 \pm 0.47 \mathrm{~g} / 100 \mathrm{ml})$, globulin $(2.80 \pm 0.47 \mathrm{~g} / 100 \mathrm{ml})$ and gamma globulin $(0.51 \pm 0.02 \mathrm{~g} / 100 \mathrm{ml})$ than the low line (total protein, $3.05 \pm 0.38$; globulin, 1.52 \pm 0.38 ; gamma globulin, $0.44 \pm 0.02$ ). Differences between the high and control lines in these parameters were non significant $(\mathrm{P}>0.05)$ although the high line was numerically higher than the control line.

Pitcovski et al. (1987) stated that chicken lines selected for high E.coli and NDV vaccines antibody response had higher levels of immunoglobulins than those selected for low response to the vaccines. Heller et al. (1992) reported that broilers of the third and fourth generations of lines selected for high antibody response against inactivated pathogenic E.coli demonstrated higher total protein and gamma globulin levels in their serum than both control and low lines.

Table(3):Least squares means \pm standard errors for serum antibody levels ( $\log _{2}$ transformed values) to inactivated NDV vaccine across three generations of selection for high and low antibody titers.

\begin{tabular}{|c|c|c|c|c|}
\hline Generation & $\begin{array}{c}\text { Number of } \\
\text { Progeny tested }\end{array}$ & $x \pm \mathbf{S E}$ & $\begin{array}{r}\text { Di } \\
(\mathbf{H}-\mathbf{L}\end{array}$ & $\begin{array}{l}\text { nce } \\
\text { H-C) }\end{array}$ \\
\hline Base & 655 & $4.56 \pm 0.07^{d}$ & - & $\%^{@}$ \\
\hline $\begin{array}{l}\text { First: } \\
\text { High line } \\
\text { Low line } \\
\text { Control line }\end{array}$ & $\begin{array}{c}185 \\
188 \\
98\end{array}$ & $\begin{array}{l}5.34 \pm 0.08^{\mathrm{c}} \\
3.70 \pm 0.11^{\mathrm{e}} \\
4.84 \pm 0.10^{\mathrm{d}}\end{array}$ & $\begin{array}{c}1.64^{* *} \\
1.14^{* *} \\
0.5^{* *}\end{array}$ & $\begin{array}{l}33.88 \\
23.55 \\
10.33\end{array}$ \\
\hline $\begin{array}{l}\text { Second: } \\
\text { High line } \\
\text { Low line } \\
\text { Control line }\end{array}$ & $\begin{array}{c}128 \\
146 \\
89\end{array}$ & $\begin{array}{l}6.25 \pm 0.09^{b} \\
2.15 \pm 0.09^{\mathrm{f}} \\
4.28 \pm 0.12^{\mathrm{d}}\end{array}$ & $\begin{array}{l}4.10^{\text {** }} \\
2.13^{\text {*** }} \\
1.97^{\text {** }}\end{array}$ & $\begin{array}{l}95.56 \\
49.77 \\
46.03 \\
\end{array}$ \\
\hline $\begin{array}{l}\text { Third: } \\
\text { High line } \\
\text { Low line } \\
\text { Control line }\end{array}$ & $\begin{array}{l}90 \\
92 \\
80\end{array}$ & $\begin{array}{l}7.17 \pm 0.09^{\mathrm{a}} \\
1.74 \pm 0.10^{\mathrm{g}} \\
4.55 \pm 0.11^{\mathrm{d}}\end{array}$ & $\begin{array}{l}5.34^{* *} \\
2.81^{* *} \\
2.62^{* *}\end{array}$ & $\begin{array}{c}117.36 \\
61.76 \\
57.58\end{array}$ \\
\hline
\end{tabular}

Means having different litters differ significantly $(\mathrm{P}>0.01)$

@ Percentage from control. 
M. A. Mandour, et al.

Table(4):Actual and expected selection differentials, intensity of selection and response to selection across three generations of selection for high and low antibody response to inactivated NDV vaccine.

\begin{tabular}{|c||c|c||c|c||c|c||c|c||}
\hline \multirow{2}{*}{ Generation } & \multicolumn{2}{c||}{ S.d of } & \multicolumn{2}{c||}{ S.d of L } & \multicolumn{2}{c||}{ Intensity of Sel. } & \multicolumn{2}{c|}{ Response to Sel } \\
\cline { 2 - 8 } & Actual & Exp & A & Exp & H & L & H & L \\
\hline \hline Base to F1 & 2.54 & 2.5 & -2.40 & -2.48 & 1.43 & 1.35 & 0.50 & -1.14 \\
F1 to F2 & 1.96 & 1.29 & -2.47 & -1.59 & 1.69 & 1.68 & 1.48 & -0.99 \\
F2 to F3 & 1.40 & 1.08 & -1.35 & -1.14 & 1.31 & 1.20 & 0.65 & -0.68 \\
Average & 1.97 & 1.62 & -2.07 & -1.74 & 1.48 & 1.41 & 0.88 & -0.93 \\
Base to F3 & 5.90 & 4.87 & -6.22 & -5.21 & - & - & 2.63 & -2.81 \\
\hline
\end{tabular}

F1 $=$ First generation $\quad F 2=$ Second generation $\quad F 3=$ Third generation

Table5:Least squares means \pm standard error, by sex for serum antibody levels ( $\log _{2}$ transformed values) to inactivated NDV vaccine across three generations of selection for high and low antibody titers.

\begin{tabular}{|c|c|c|c|}
\hline Generation\& line & Sex & Number & $\times \pm$ S.E. \\
\hline Base & $\begin{array}{l}\text { Male } \\
\text { Female }\end{array}$ & $\begin{array}{r}303 \\
352 \\
\end{array}$ & $\begin{array}{l}4.49 \pm 0.10 \\
4.61 \pm 0.09\end{array}$ \\
\hline \multirow{2}{*}{$\begin{array}{l}\text { First: } \\
\text { High line }\end{array}$} & Male & 96 & $5.44 \pm 0.11$ \\
\hline & Female & 89 & $5.23 \pm 0.13$ \\
\hline \multirow{2}{*}{ Low line } & Male & 91 & $3.71 \pm 0.15$ \\
\hline & Female & 97 & $3.68 \pm 0.16$ \\
\hline \multirow{2}{*}{ Control line } & Male & 54 & $4.79 \pm 0.15$ \\
\hline & Female & 44 & $4.89 \pm 0.14$ \\
\hline \multirow{2}{*}{$\begin{array}{l}\text { Second: } \\
\text { High line }\end{array}$} & & & \\
\hline & $\begin{array}{l}\text { Male } \\
\text { Female }\end{array}$ & $\begin{array}{l}01 \\
67\end{array}$ & $\begin{array}{l}0.20 \pm 0.14 \\
6.23 \pm 0.13\end{array}$ \\
\hline \multirow{2}{*}{ Low line } & Male & 63 & $2.20 \pm 0.15$ \\
\hline & Female & 83 & $2.11 \pm 0.12$ \\
\hline \multirow{2}{*}{ Control line } & Male & 38 & $4.14 \pm 0.21$ \\
\hline & Female & 51 & $4.39 \pm 0.15$ \\
\hline \multirow{2}{*}{$\begin{array}{l}\text { Third: } \\
\text { High line }\end{array}$} & Male & 45 & $7.20 \pm 0.13$ \\
\hline & Female & 45 & $7.14 \pm 0.13$ \\
\hline \multirow{2}{*}{ Low line } & Male & 45 & $1.75 \pm 0.08$ \\
\hline & Female & 47 & $1.73 \pm 0.07$ \\
\hline \multirow{2}{*}{ Control line } & Male & 40 & $4.62 \pm 0.11$ \\
\hline & Female & 40 & $4.48 \pm 0.12$ \\
\hline
\end{tabular}

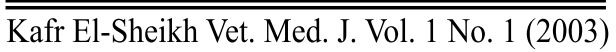


Selection For Immune Response In Japanese Quails

Table6:Least squares means \pm standard errors for quail body weight (combined sex) at hatch, two weeks, four weeks and six weeks of age across three generations of selection for high and low antibody titers to NDV vaccine.

\begin{tabular}{|c||c||c||c||c||c||c||}
\hline Base & & $\mathbf{6 5 5}$ & $\mathbf{7 . 5 9} \pm \mathbf{0 . 0 3} \mathbf{b}$ & $\mathbf{3 9 . 3 9} \pm \mathbf{0 . 1 3} \mathbf{~ a b}$ & $\mathbf{8 8 . 2 1} \pm \mathbf{0 . 5 3} \mathbf{~ b}$ & $\mathbf{1 2 5 . 7 4 \pm 0 . 4 5} \mathbf{c}$ \\
\hline \hline \multirow{3}{*}{ First } & $\mathrm{H}$ & 185 & $7.65 \pm 0.07 \mathrm{~b}$ & $39.81 \pm 0.36 \mathrm{a}$ & $86.70 \pm 0.86 \mathrm{~b}$ & $125.36 \pm 0.76 \mathrm{c}$ \\
& $\mathrm{L}$ & 188 & $7.61 \pm 0.06 \mathrm{~b}$ & $39.37 \pm 0.34 \mathrm{ab}$ & $85.32 \pm 0.82 \mathrm{~b}$ & $125.01 \pm 0.82 \mathrm{c}$ \\
& $\mathrm{C}$ & 98 & $7.74 \pm 0.05 \mathrm{~b}$ & $39.17 \pm 0.24 \mathrm{ab}$ & $87.85 \pm 0.66 \mathrm{~b}$ & $125.79 \pm 0.76 \mathrm{c}$ \\
\hline \multirow{3}{*}{ Second } & $\mathrm{H}$ & 128 & $7.97 \pm 0.06 \mathrm{a}$ & $39.70 \pm 0.10 \mathrm{ab}$ & $93.08 \pm 0.88 \mathrm{a}$ & $128.99 \pm 0.86 \mathrm{ab}$ \\
& $\mathrm{L}$ & 146 & $7.57 \pm 0.06 \mathrm{~b}$ & $39.02 \pm 0.14 \mathrm{~b}$ & $86.25 \pm 0.72 \mathrm{~b}$ & $124.33 \pm 0.75 \mathrm{c}$ \\
& $\mathrm{C}$ & 89 & $7.92 \pm 0.09 \mathrm{~b}$ & $39.32 \pm 0.15 \mathrm{ab}$ & $87.99 \pm 1.11 \mathrm{~b}$ & $126.52 \pm 1.10 \mathrm{bc}$ \\
\hline \multirow{3}{*}{ Third } & $\mathrm{H}$ & 90 & $7.80 \pm 0.08 \mathrm{a}$ & $39.76 \pm 0.17 \mathrm{ab}$ & $91.70 \pm 0.85 \mathrm{a}$ & $130.32 \pm 1.19 \mathrm{a}$ \\
& $\mathrm{L}$ & 92 & $7.50 \pm 0.06 \mathrm{~b}$ & $39.30 \pm 0.19 \mathrm{ab}$ & $86.30 \pm 1.14 \mathrm{~b}$ & $125.14 \pm 0.94 \mathrm{c}$ \\
& $\mathrm{C}$ & 80 & $7.60 \pm 0.05 \mathrm{~b}$ & $39.33 \pm 0.14 \mathrm{ab}$ & $88.42 \pm 0.90 \mathrm{~b}$ & $126.30 \pm 1.16 \mathrm{c}$ \\
\hline
\end{tabular}

Means having the same litter in the same column do not differ significantly $(\mathrm{P}>0.05)$
$\mathrm{H}=$ high
$\mathrm{L}=$ low
$\mathrm{C}=$ control

Table7: Actual correlated response to selection (differences between means of the same line in successive generations) for high and low antibody titer to NDV vaccine in body weight (grams) at hatch, 2-week, 4-week and 6-week.

\begin{tabular}{|l||c|c||c|c||c|c||c|c||}
\hline \multirow{2}{*}{ Generation } & \multicolumn{2}{|c||}{ Hatch $(\mathrm{g})$} & \multicolumn{2}{c||}{ 2-week $(\mathrm{g})$} & \multicolumn{2}{c||}{ 4-week $(\mathrm{g})$} & \multicolumn{2}{|c|}{ 6-week $(\mathrm{g})$} \\
\cline { 2 - 8 } & High & Low & High & Low & High & Low & High & Low \\
\hline \hline \multirow{2}{*}{ Base to F1 } & 0.06 & 0.02 & 0.42 & -0.02 & -1.51 & -2.89 & -0.38 & -0.73 \\
F1 to F2 & $0.32 * *$ & -0.08 & -0.11 & -0.35 & $-6.30 * *$ & 0.93 & $3.63 * *$ & -0.68 \\
F2 to F3 & -0.17 & -0.07 & 0.06 & -0.28 & -1.38 & 0.05 & 1.33 & 0.81 \\
Base to F3 & 0.21 & -0.09 & 0.37 & -0.09 & $3.49 * *$ & 0.09 & $4.58 * *$ & -0.6 \\
\hline
\end{tabular}

** Highly significant

Means having the same litter in the same column do not differ significantly $(\mathrm{P}>0.05)$

$$
\mathrm{H}=\text { High } \quad \mathrm{L}=\text { Low } \quad \mathrm{C}=\text { Control }
$$


M. A. Mandour, et al.

Table(8):Means \pm standard errors for fertility and hatchability across three generations of selection for high and low antibody titers.

\begin{tabular}{|c||c||c||c||}
\hline Gen & Line & Fertility \% & Hatchability \% \\
\hline \hline \multirow{3}{*}{ Base } & High & $83.09 \pm 2.20 \mathrm{c}$ & $70.38 \pm 1.69 \mathrm{c}$ \\
& Low & $94.87 \pm 2.30 \mathrm{a}$ & $73.53 \pm 1.72 \mathrm{c}$ \\
& Control & $88.73 \pm 3.00 \mathrm{ab}$ & $76.63 \pm 1.82 \mathrm{~b}$ \\
\hline \multirow{3}{*}{ First } & High & $86.33 \pm 3.34 \mathrm{bc}$ & $79.28 \pm 2.97 \mathrm{~b}$ \\
& Low & $90.11 \pm 2.81 \mathrm{ab}$ & $80.29 \pm 2.30 \mathrm{ab}$ \\
& Control & $89.05 \pm 2.89 \mathrm{ab}$ & $76.96 \pm 2.48 \mathrm{~b}$ \\
\hline \multirow{3}{*}{ Second } & High & $85.50 \pm 2.34 \mathrm{bc}$ & $84.70 \pm 2.87 \mathrm{a}$ \\
& Low & $90.82 \pm 2.16 \mathrm{ab}$ & $80.30 \pm 4.24 \mathrm{ab}$ \\
& Control & $89.01 \pm 2.79 \mathrm{ab}$ & $77.00 \pm 5.18 \mathrm{~b}$ \\
\hline \multirow{3}{*}{ Third } & High & $84.10 \pm 1.60 \mathrm{bc}$ & $70.81 \pm 2.67 \mathrm{c}$ \\
& Low & $91.59 \pm 2.96 \mathrm{a}$ & $73.32 \pm 2.44 \mathrm{c}$ \\
& Control & $89.13 \pm 2.75 \mathrm{ab}$ & $76.36 \pm 2.35 \mathrm{bc}$ \\
\hline
\end{tabular}

Means having the same litter in the same column do not differ significantly $(\mathrm{P}>0.05)$.

Table9:Correlated response to selection (difference between successive generations of the same line) in fertility and hatchability percentages across three generations of selection for high and low antibody titer to NDV vaccine.

\begin{tabular}{|l||c|c||c|c||}
\hline \multirow{2}{*}{ Generation } & \multicolumn{2}{|c||}{ Fertility \% } & \multicolumn{2}{c||}{ Hatchability \% } \\
\cline { 2 - 5 } & High & Low & High & Low \\
\hline \hline \multirow{2}{*}{ Base to F1 } & 3.24 & -4.76 & $8.90^{* *}$ & $6.76^{* *}$ \\
F1 to F2 & -0.83 & 0.71 & $5.42^{* *}$ & 0.01 \\
F2 to F3 & -1.40 & 0.77 & $-13.89^{* *}$ & $-6.98^{* *}$ \\
Base to F3 & 1.01 & 3.28 & 0.43 & -0.21 \\
\hline
\end{tabular}

** Highly significant 
Table(10):Least square means \pm standard errors for egg number and egg weight during first 45 days of production across three generations of selection for high and low antibody titers.

\begin{tabular}{||c||l||l||c||}
\hline Generation & Line & Egg number & Egg weight (g) \\
\hline \hline \multirow{3}{*}{ Base } & High & $33.16 \pm 0.54 \mathrm{a}$ & $10.57 \pm 0.14 \mathrm{a}$ \\
& Low & $33.05 \pm 0.48 \mathrm{a}$ & $10.47 \pm 0.12 \mathrm{ab}$ \\
& Control & $31.91 \pm 0.55 \mathrm{a}$ & $10.56 \pm 0.13 \mathrm{a}$ \\
\hline \multirow{3}{*}{ First } & High & $32.85 \pm 0.63 \mathrm{a}$ & $10.67 \pm 0.14 \mathrm{a}$ \\
& Low & $34.77 \pm 0.43 \mathrm{a}$ & $10.57 \pm 0.13 \mathrm{a}$ \\
& Control & $31.99 \pm 0.77 \mathrm{a}$ & $10.57 \pm 0.12 \mathrm{a}$ \\
\hline \multirow{3}{*}{ Second } & High & $31.89 \pm 0.43 \mathrm{a}$ & $10.38 \pm 0.14 \mathrm{ab}$ \\
& Low & $32.38 \pm 0.52 \mathrm{a}$ & $09.90 \pm 0.13 \mathrm{c}$ \\
& Control & $31.95 \pm 0.41 \mathrm{a}$ & $10.57 \pm 0.15 \mathrm{a}$ \\
\hline \multirow{3}{*}{ Third } & High & $30.97 \pm 0.445 \mathrm{a}$ & $10.57 \pm 0.13 \mathrm{a}$ \\
& Low & $33.32 \pm 0.40 \mathrm{a}$ & $10.25 \pm 0.11 \mathrm{~b}$ \\
& Control & $31.94 \pm 0.39 \mathrm{a}$ & $10.57 \pm 0.12 \mathrm{a}$ \\
\hline
\end{tabular}

Means having the same litter in the same column do not differ significantly $(\mathrm{P}>0.05)$.

Table11:Correlated response to selection (difference between means in successive generations) in egg number and egg weight during the first 45 day of production across three generations of divergent selection for antibody titer to NDV vaccine.

\begin{tabular}{|l||c|c||c|c||}
\hline \multirow{2}{*}{ Generation } & \multicolumn{2}{|c||}{ Egg number (egg) } & \multicolumn{2}{c||}{ Egg weight (g) } \\
\cline { 2 - 5 } & High & Low & High & Low \\
\hline \hline Base to F1 & 0.69 & 1.72 & 0.10 & 0.10 \\
F1 to F2 & 0.96 & 2.93 & -0.29 & -0.67 \\
F2 to F3 & 0.92 & 0.94 & 0.19 & 0.35 \\
Base to F3 & 1.19 & 0.27 & 0.00 & -0.22 \\
\hline
\end{tabular}

$\overline{\overline{\text { Kafr El-Sheikh Vet. Med. J. Vol. } 1 \text { No. } 1 \text { (2003) }}}$ 
M. A. Mandour, et al.

Table(12):Least square means \pm standard errors for phagocytic activity and phagocytic index in the high, low and control lines during the third generation of selection for high and low antibody titer to NDV vaccine.

\begin{tabular}{|l||c||c||}
\hline \multicolumn{1}{|c||}{ Line } & Phagocytic activity \% & Phagocytic index \\
\hline \hline High & $26.00 \pm 1.00 \mathrm{a}$ & $8.51 \pm 0.47 \mathrm{a}$ \\
Low & $30.00 \pm 2.00 \mathrm{a}$ & $7.98 \pm 0.39 \mathrm{a}$ \\
Control & $30.00 \pm 2.00 \mathrm{a}$ & $8.04 \pm 0.75 \mathrm{a}$ \\
\hline
\end{tabular}

Means having the same litter in the same column do not differ significantly $(\mathrm{P}>0.05)$.

Table(13):Least square means \pm standard errors for serum protein, serum albumen, serum globulin and gamma globulin in the high, low and control lines during the third generation of selection for high and low antibody titer to NDV vaccine.

\begin{tabular}{||l||c||c||c||c||}
\hline \multicolumn{1}{|c||}{ Line } & $\begin{array}{c}\text { Serum protein } \\
(\mathbf{g} / \mathbf{1 0 0} \mathbf{~ m l})\end{array}$ & $\begin{array}{c}\text { Serum albumen } \\
(\mathbf{g} / \mathbf{1 0 0} \mathbf{~ m l})\end{array}$ & $\begin{array}{c}\text { Serum globulin } \\
(\mathbf{g} / \mathbf{1 0 0} \mathbf{~ m l})\end{array}$ & $\begin{array}{c}\text { Gamma globulins } \\
(\mathbf{g} / \mathbf{1 0 0} \mathbf{~ m l})\end{array}$ \\
\hline \hline High & $4.61 \pm 0.47 \mathrm{a}$ & $1.80 \pm 0.26 \mathrm{a}$ & $2.80 \pm 0.47 \mathrm{a}$ & $0.51 \pm 0.02 \mathrm{a}$ \\
Low & $3.05 \pm 0.38 \mathrm{~b}$ & $1.52 \pm 0.16 \mathrm{a}$ & $1.52 \pm 0.38 \mathrm{~b}$ & $0.44 \pm 0.02 \mathrm{~b}$ \\
Control & $3.83 \pm 0.35 \mathrm{ab}$ & $1.48 \pm 0.17 \mathrm{a}$ & $2.35 \pm 0.41 \mathrm{ab}$ & $0.46 \pm 0.02 \mathrm{ab}$ \\
\hline
\end{tabular}

Means having the same litter in the same column do not differ significantly $(\mathrm{P}>0.05)$.

\section{REFERENCES}

- Bahie El-Dean, M. (1990): Selection and correlated responses for dressing percentage in Japanese quail. M. Sc. Thesis, Agric. College, Alex. Univ. Alexandria, Egypt.

- Bartholomew, R. J. and Delancy (1966): Proc. Asut. Biochemists, I: 241. Cited in H. Varely, A. H. Growenlok and M. Bell (1980): Practical Clinical Biochemistry. William Heinemann Medical Books LTD, London.

- Biozzi, G.; Mouton; O.A. Sant Anna; and M. Sigueira (1979): Genetics of immunoresponsiveness to natural antigens in mouse. Current Topics Microbial. Immunol. 85:31-98.

$\overline{\text { Kafr El-Sheikh Vet. Med. J. Vol. } 1 \text { No. } 1 \text { (2003) }}$ 
- Ching, S and S.J. Lamont (1988): Genetic analysis of immunocompetence measures in a White Leghorn chicken line. Poultry Sci. 67: 989-995.

- Coles, E. H. (1974): Veterinary clinical pathology. Sounders Company, Philadelphia and London.

- Dunnington, E.A.; W.E. Briles; R.W. Briles and P.P. Siegel (1996): Immunoresponsiveness in chickens: Association of antibody production and the B-system of the major histocompatability complex. Poultry Sci. 75: 1156-1160.

- Gomez, K. A. and A. A.Gomez.(1984):Statistical procedures for agricultural Research. $2^{\text {nd }}$ edition, International Research Institute, USA.

- Graham, H., L. H. A.Lawrence, C.H.Domermuth and J.E.Pearson (1989): A laboratory manual for the isolation and identification of avian pathogens. Third Edition, American Association of Avian Pathologists. University of Pennsylvania. USA.

- Heller, E. D.;G. Leitner;A.Friedman; Z. Uni; M. Gutman and A. Cahaner (1992): Immunological parameters in meat-type chicken lines divergently selected by antibody response to Escherichia coli vaccination. Vet. Immunol. Immunopathol., 34: 159-172.

- Kawahara,E.;T.Uada and S. Nomura.(1991):In vitro phagocytic activity of White spotted shark blood cells after injection with Aeromonas Salmonicida extracellular products. Gyobyo Kenkyu, Japan, 26 (4): 213-214.

- Kreukniet,M.B.;M.G.Nieuwland;and A.J.Van der Zijpp(1995): Phagocytic activity of two lines of chickens divergently selected for antibody production. Vet. Immunol. Immunopathol., 44: 3-4.

- Leitner,G.;Z.Uni;A.Cahaner;W.Gutman and E.D.Heller(1992):Replicated divergent selection of broiler chickens for high and low early antibody response to Echerichia coli. Poultry Sci., 71: 27-37.

- Martin, A.; E. A. Dunnington; W.B. Gross; W.E. Briles; R.W. Briles and Siegel (1990): Production traits and alloantigen systems in lines of chickens selected for high and low antibody responses to sheep erythrocytes. Poultry Sci., 69: 871-878.

- Parmentier,H.K.;M.G.B.Nieuwland;E.Rijke;G.De Vries Reilingh and J. W.Schrama.(1996):Divergent antibody responses to vaccines and divergent body weights of chicken lines selected for high and low humoral responsiveness to sheep red blood cells. Avian Dis., 40: 634-644. 
- Pinard, M.H.; J.A.M. Von Aren donk; M.G.B.Nieuwland and A.J. van der Zijpp(1992):Divergent selection for immune responsiveness in chickens: Estimation of realized heritability with an animal model. J. Anim. Sci., 70: 2986-2993.

- Pitcovski,J.; D.E. Heller; A. Cahaner and B.A. Peleg (1987): Selection for early responsiveness of chicks to Escherichia coli and Newcastle disease virus. Poultry Sci., 66: 1276-1282.

- $\quad \boldsymbol{S A S ( 1 9 8 7 ) : S A S / S T A T ; U s e r ' s ~ G u i d : ~ S t a t i s t i c s . S A S ~ I n s t i t u t e ~ I N C . , C a r y . ~ N C . ~}$

- Siegle, P.B.and W.B.Gross (1980):Production and persistence of antibodies in chickens to sheep erythrocytes.Directional selection.Poultry Sci.,59:1-6.

- Stoot,G.H.and A.Fellah(1983):Colostral immunoglobulin absorption nearly related to concentration for calves .J. dairy Sci., 66: 1315-1328.

- Takahashi,S.;S. Inooka and Y. Mizuma (1984): Selective breeding for high and low antibody responses to inactivated Newcastle disease virus vaccine in Japanese quail. Poultry Sci., 63: 595-599.

- Van der Zijpp, A.J. (1983): The effect of genetic origin, source of antigen and dose of antigen on the immune response of cockerels. Poultry Sci., 62: 205-211.

- Walfson, W. Q.; G. Cohn; E. Calvary and I. Chiba (1948): Amer. J. Clin. Path. 18: 728. Cited in H. Varely, A. H. Growenlok and M. Bell (1980): Practical Clinical Biochemistry. William Heinemann Medical Books LTD, London.

- Weichselbaum,T.E.(1946): An accurate and rapid method for determination of protein in small amount of blood serum and plasma. Am. J. Clin. Path., 16:40-49. 